\title{
PENGARUH HARGA DAN LOKASI TERHADAP KEPUASAN ORANG TUA MURID DI MI MATHLAUL ANWAR PAMULANG
}

\author{
Zakaria \\ Universitas Pamulang \\ Email: dosen02357@unpam.ac.id
}

\begin{abstract}
Purpose. This study aims to determine the effect of price and location on parental satisfaction at MI Mathlaul Anwar Pamulang.

Methods. The method used in this research is a survey method. The population in this study were all parents of students at MI Mathlaul Anwar Pamulang, while the number of samples used was 70 respondents. The data analysis technique in this study uses Partial Least Square (PLS).

Findings. The results of this study are the price has a significant effect on the satisfaction of parents at MI Mathlaul Anwar Pamulang, it shows that the increase in prices is reasonable and still affordable by the ability of parents of students, then the satisfaction of parents at MI Mathlaul Anwar Pamulang will also increase. Location has a significant influence on parental satisfaction at MI Mathlaul Anwar Pamulang, it shows that the more strategic the location of the school and easy access for students, the greater the satisfaction of parents at MI Mathlaul Anwar Pamulang.

Implication. This research is expected to provide input for MI Mathlaul Anwar Pamulang on how to increase parental satisfaction which can be done by paying attention to price and location factor.
\end{abstract}

Keywords. Price, Location, Parental Satisfaction.

\begin{abstract}
ABSTRAK
Tujuan. Penelitian ini bertujuan untuk mengetahui pengaruh harga dan lokasi Terhadap Kepuasan Orang Tua Murid di MI Mathlaul Anwar Pamulang.

Metode. Metode yang digunakan dalam penelitian adalah metode survey. Populasi dalam penelitian ini adalah seluruh Orang Tua Murid di MI Mathlaul Anwar Pamulang, sedangkan jumlah sampel yang digunakan sebanyak 70 responden. Teknik analisis data dalam penelitian ini menggunakan Partial Least Square (PLS).

Hasil. Hasil dari penelitian ini adalah harga memberikan pengaruh signifikan terhadap kepuasan Orang Tua Murid di MI Mathlaul Anwar Pamulang, hal tersebut menunjukan bahwa peningkatan harga yang wajar serta masih terjangkau oleh kemampuan Orang Tua Murid, maka kepuasan Orang Tua Murid di MI Mathlaul Anwar Pamulang juga akan meningkat. Lokasi memberikan pengaruh signifikan terhadap kepuasan Orang Tua Murid di MI Mathlaul Anwar Pamulang, hal tersebut menunjukan bahwa semakin strategis lokasi sekolah dan mudah di akses oleh peserta didik maka akan meningkatkan kepuasan Orang Tua Murid di MI Mathlaul Anwar Pamulang.

Implikasi. Penelitian ini diharapkan dapat memberikan masukan bagi MI Mathlaul Anwar Pamulang tentang bagaimana meningkatkan kepuasan orang tua murid yang dapat dilakukan dengan cara memperhatikan faktor harga dan lokasi.
\end{abstract}

Kata Kunci : Harga, Lokasi, Kepuasan Orang Tua. 


\section{Pendahuluan}

Persaingan dalam industri jasa pendidikan setiap tahun mengalami peningkatan persaingan yang cukup ketat, dengan adanya persaingan yang ketat ini membuat pihak lembaga pendidikan mau tidak mau harus mengeluarkan segenap daya dan tenaga untuk membuat calon siswa menjadi tertarik untuk mau bersekolah di lembaga pendidikan tersebut, (Oktarini dan Rahmayanti, 2020). Pemasaran sangat berkaitan erat dengan pelanggan yang saling melengkapi, dan biasanya dengan adanya pemasaran akan memberikan kemudahan para pelanggan untuk mencari jasa atau barang yang dibutuhkan oleh pelanggan, (Prasetia, 2019).

Orang tua siswa sebagai pelanggan eksternal sekunder tentunya sangat berperan penting dalam menentukan pilihan lembaga sekolah untuk anaknya. Masing-masing orang tua siswa mempunyai kriteria sendiri dalam menentukan sekolah untuk anaknya. Umumnya yang menjadi pertimbangan untuk memilih sekolah adalah kurikulum dan program kegiatan yang akan diterapkan, sarana prasarana, kebijakan yayasan mengenai biaya pendidikan, staf pengajar, kepemimpinan kepala sekolah, prestasi yang dicapai sekolah, image masyarakat tentang sekolah tersebut, lokasi sekolah, dan lingkungan sekolah. Tetapi satu hal penting yang perlu mendapat perhatian khusus adalah mengenai kepuasan orang tua siswa terhadap layanan yang diberikan oleh sekolah, (Arif, 2016).

Madrasah Ibtidaiyah (MI) Mathla'ul Anwar merupakan salah satu sekolah tingkat dasar swasta yang bertempat di Jalan H. Rean RT 03/01 Kelurahan Benda Baru, Kecamatan Pamulang, Kota Tangerang Selatan. Mi Mathla'ul Anwar telah didirikan sejak tahun 1973, dan mendapatkan SK Ijin Operasional pada tanggal 17 Nopember 1990, dari kantor wilayah kementerian agama propinsi Jawa Barat. Hal ini, setelah dibentuk menjadi suatu yayasan, yaitu Yayasan Al Ishlah Benda Baru Pamulang.

Berdasarkan hasil observasi yang penulis lakukan ditemukan persoalan biaya pendidikan di MI Mathla'ul Anwar Pamulang yang berada dalam posisi yang membingungkan. Karena sebagai sekolah swasta, MI Mathla'ul Anwar perlu menarik biaya pendidikan tambahan setiap bualn untuk peserta didiknya. Biaya pendidikan di Mimathla'ul Anwar setiap peserta didik yaitu Rp. 50.000 / bulan, menurut penulis biaya pendidikan tersebut tidak ideal. Namun, jika dibandingkan dengan pesaing sekolah terdekat yaitu Sekolah Negeri yang gratis, maka untuk menaikan biaya pendidikan akan sangat menjadi pertimbangan.

Secara geografis lokasi MI Mathla'ul Anwar cukup berada di wilayah strategis dari kantor pemerintahan daerah Kota Tangerang Selatan yaitu sekitar 3 KM. Akan tetapi, letak sekolah MI Mathla'ul Anwar bukan berada pada jalan kota maupun jalan propinsi, tepatnya berada di wilayah lingkungan pemukiman/perumahan warga. Lokasi yang tidak strategis akan membuat konsumen tidak nyaman. Iskandarsyah dan Utami (2017) menyatakan bahwa memilih tempat atau lokasi yang baik merupakan keputusan yang penting, bagi para pelanggan dalam menentukan sebuah pilihan.

Berdasarkan latar belakang diatas, maka peneliti tertarik untuk mengadakan penelitian dengan judul Pengaruh Harga Dan Lokasi Terhadap Kepuasan Orang Tua Murid di MI Mathlaul Anwar Pamulang.

\section{Kajian Pustaka dan Hipotesis}

Harga. Menurut Kotler dan Armstrong (2016), harga adalah sejumlah uang yang dibebankan atas suatu barang atau jasa atau jumlah dari nilai uang yang ditukar konsumen atas manfaatmanfaat karena memiliki atau menggunakan produk atau jasa tersebut. Menurut Tjiptono (2016), secara sederhana istilah harga dapat diartikan "sebagai jumlah uang (satuan moneter) dan/atau aspek lain (non moneter) yang mengandung utilitas/kegunaan tertentu yang diperlukan untuk mendapatkan suatu jasa". Sedangkan menurut Alma (2016) "Harga sebagai nilai suatu barang yang dinyatakan dengan uang". Harga memiliki dua peranan utama dalam proses pengambilan keputusan para pembeli, yaitu peranan alokasi dan peranan informasi.

Berdasarkan penjelasan dari para ahli diatas maka dapat disimpulkan bahwa harga adalah nilai uang yang ditentukan secara global yang harus dikeluarkan oleh seseorang untuk mendapatkan suatu produk atau pelayanan jasa yang di inginkan dan sangat terlihat jelas 
bahwa harga sangat berpengaruh bagi perekonomian, konsumen dan bagi perusahaan. Maka dari itu, penetapan harga pada sebuah produk harus sesuai karena harga dapat memberikan keuntungan (profit) bagi perusahaan dalam jangka pendek maupun jangka panjang.

Menurut Singal, Koleangan, dan Sepang (2019), indikator variabel harga yaitu sebagai berikut:

1) Keterjangkauan harga

Konsumen bisa menjangkau harga yang telah ditetapkan oleh perusahaan Produk biasanya ada beberapa jenis dalam satu merek harganya juga berbeda dari yang termurah sampai termahal.

2) Kesesuaian harga dengan kualitas produk

Harga sering dijadikan sebagai indikator kualitas bagi konsumen orang sering memilih harga yang lebih tinggi diantara dua barang karena mereka melihat adanya perbedaan kualitas. Apabila harga lebih tinggi orang cenderung beranggapan bahwa kualitasnya juga lebih baik.

3) Daya saing harga

Konsumen sering membandingkan harga suatu produk dengan produk lainnya, dalam hal ini mahal murahnya suatu produk sangat dipertimbangkan oleh konsumen pada saat akan membeli produk.

4) Kesesuaian harga dengan manfaat

Konsumen memutuskan membeli suatu produk jika manfaat yang dirasakan lebih besar atau sama dengan yang telah dikeluarkan untuk mendapatkannya. Jika konsumen merasakan manfaat produk lebih kecil dari uang yang dikeluarkan maka konsumen akan beranggapan bahwa produk tersebut mahal dan konsumen akan berpikir dua kali untuk melakukan pembelian ulang

Lokasi. Menurut Tjiptono (2016:345) Lokasi mengacu pada berbagai aktivitas pemasaran yang berusaha memperlancar dan mempermudah penyampaian atau penyaluran barang dan jasa dari produsen kepada konsumen. Sedangkan menurut Kotler dan Amstrong (2016:76) "place include company activities that make the product available to target consumers". Kemudian menurut Lupiyoadi dan Hamdani (2011:92) "lokasi adalah keputusan yang dibuat perusahaan atau instansi pendidikan berkaitan dengan di mana operasi dan stafnya akan ditempatkan".

Suatu lokasi disebut strategis bila berada dipusat kota, kepadatan populasi, kemudahan mencapainya menyangkut kemudahan transportasi umum, kelancaran lalu lintas dan arahnya tidak membingungkan konsumen. Sejalan dengan menjamurnya bisnis atau usaha yang menawarkan produk atau jasa yang sejenis, perbedaannya yang sangat tipis sekalipun pada lokasi dapat berdampak kuat pada pangsa pasar dan kemampulabaan sebuah produk. Adapun faktor-faktor yang harus dipertimbangkan dalam menentukan pertimbangan-pertimbangan yang cermat dalam menentukan lokasi menurut Kotler (2016:84) meliputi faktor:

1) Akses, misalnya lokasi yang mudah dilalui atau mudah dijangkau sarana transportasi umum.

2) Visibilitas, misalnya lokasi dapat dilihat dengan jelas dari tepi jalan.

3) Tempat parkir yang luas dan aman

4) Ekspansi, yaitu tersedia tempat yang cukup luas untuk peluasan usaha di kemudian hari.

5) Lingkungan, yaitu daerah sekitar yang mendukung jasa yang ditawarkan.

Kepuasan. Menurut Richard L. Oliver dalam Tjiptono \& Diana (2015:23) Kepuasan Pelanggan adalah perasaan senang atau kecewa yang didapatkan seseorang dari membandingkan antara kinerja (atau hasil) produk yang dipersepsikan dan ekspektasinya. Seorang pelanggan puas atau tidak, sangat tergantung pada kinerja produk (Percieved Performance) dibandingkan ekspektasi pelanggan bersangkutan dan apakah sang pelanggan menginterpretasikan adanya deviasi atau gap di antara kinerja dan ekspektasi tersebut. Apabila kinerja lebih rendah di bandingkan ekspektasi, maka pelanggan bersangkutan akan merasa tidak puas. Apabila kinerja sama dengan ekspektasi, maka ia akan puas. Sedangkan jika kinerja melampaui ekspektasi, maka pelanggan itu akan merasa sangat puas atau bahkan bahagia (Delighted). Windasuri \& 
Hyacintha (2016:64) menambahkan kepuasan pelanggan adalah suatu tanggapan emosional pada evaluasi terhadap pengalaman konsumsi suatu produk atau jasa:

Hal yang dapat mempengaruhi kepuasan pelanggan dapat dilihat dari ukuran atau dimensi kepuasan pelanggan menurut Kotler \& Keller (2016) sebagai berikut.

1) Tetap Setia

Pelanggan yang terpuaskan cenderung akan menjadi setia atau loyal. Pelanggan yang puas terhadap produk yang dikonsumsinya akan mempunyai kecenderungan untuk membeli ulang dari produsen yang sama.

2) Membeli Produk yang ditawarkan

Keinginan untuk membeli produk atau makanan lain yang ditawarkan karena adanya keinginan untuk mengulang pengalaman yang baik dan menghindari pengalaman yang buruk.

3) Merekomendasikan Produk

Kepuasan merupakan faktor yang mendorong adanya komunikasi dari mulut ke mulut (Word of Mouth Communication) yang bersifat positif. Hal ini dapat berupa rekomendasi kepada calon pelanggan yang lain danmengatakan hal-hal baik mengenai produk dan perusahaan yang menyediakan produk.

4) Bersedia Membayar Lebih

Pelanggan cenderung menggunakan harga sebagai patokan kepuasan. Ketika harga lebih tinggi, pelanggan cenderung berfikir kualitas menjadi lebih tinggi juga

5) Memberi Masukan

Walaupun kepuasan sudah tercapai, pelanggan selalu menginginkan yang lebih lagi. Maka pelanggan akan memberikan masukan atau saran agar keinginan mereka dapat tercapai.

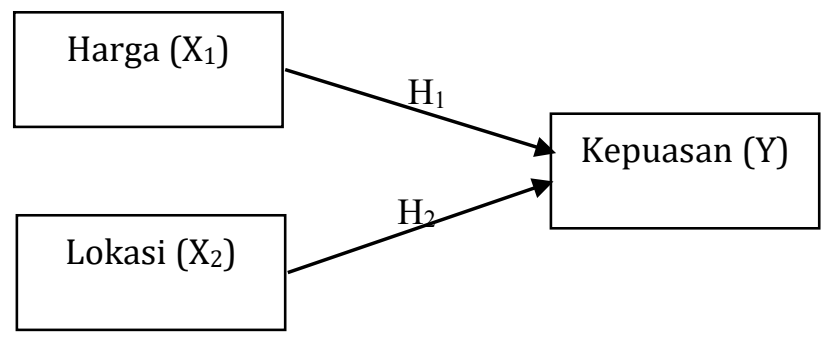

Gambar 1. Model Penelitian

\section{Hipotesis}

H1: Diduga Harga berpengaruh signifikan terhadap kepuasan Orang Tua Murid Di MI Mathlaul Anwar Pamulang

H2 : Diduga Lokasi berpengaruh signifikan terhadap kepuasan Orang Tua Murid Di MI Mathlaul Anwar Pamulang

\section{Metode Penelitian}

Jenis penelitian yang digunakan pada penelitian ini yaitu menggunakan metode kuantitatif jenis metode survei. Sugiyono (2017) menyatakan bahwa: "Penelitian survei adalah penelitian yang dilakukan pada populasi besar maupun kecil, tetapi data yang dipelajari adalah data dari sampel yang diambil dari populasi tersebut, untuk menemukan kejadian-kejadian relatif, distribusi, dan hubungan-hubungan antara variabel sosiologis maupun psikologis".

Populasi dalam penelitian ini adalah seluruh Orang Tua Murid di MI Mathlaul Anwar Pamulang. Penentuan jumlah sampel minimal pada penelitian ini mengacu pada pernyataan Hair et al (2015) bahwa banyaknya sampel sebagai responden harus disesuaikan dengan banyaknya indikator pertanyaan yang digunakan pada kuesioner, Sehingga disarankan bahwa ukuran sampel minimum adalah 5-10 observasi untuk setiap parameter yang diestimasi dengan asumsi $\mathrm{n} \times 5$ observed variable (indikator). Dalam penelitian ini jumlah indikator harga sebanyak 4 indikator, lokasi 5 indikator dan kepuasan sebanyak 5 indikator maka keseluruhan indikator sebanyak 14 indikator. Sehingga pengambilan sampel menggunakan rumus Hair et al 
(2015) sebagai berikut: Sampel $=14 \times 5=70$ responden. Berdasarkan perhitungan tersebut maka jumlah sampel yang digunakan dalam penelitian ini berjumlah 70 responden.

Teknik analisis data dalam penelitian ini menggunakan Partial Least Square (PLS). PLS merupakan model persamaan Structural Equation Modeling (SEM) dengan pendekatan berdasarkan variance atau componentbased structural equation modeling. Menurut Latan dan Ghozali (2017), tujuan PLS-SEM adalah untuk mengembangkan teori atau membangun teori (orientasi prediksi). PLS digunakan untuk menjelaskan ada tidaknya hubungan antar variabel laten (prediction). PLS merupakan metode analisis yang powerfull oleh karena tidak mengasumsikan data arus dengan pengukuran skala tertentu, jumlah sample kecil.

\section{Hasil Penelitian dan Pembahasan Measurement (Outer) Model Evaluation}

Pengujian Convergent Validity dari model pengukuran dengan refleksif indikator dinilai berdasarkan korelasi antara item score atau component score dengan construct score yang dihitung dengan PLS. Indikator individu dianggap valid jika memiliki nilai korelasi di atas 0.70 .

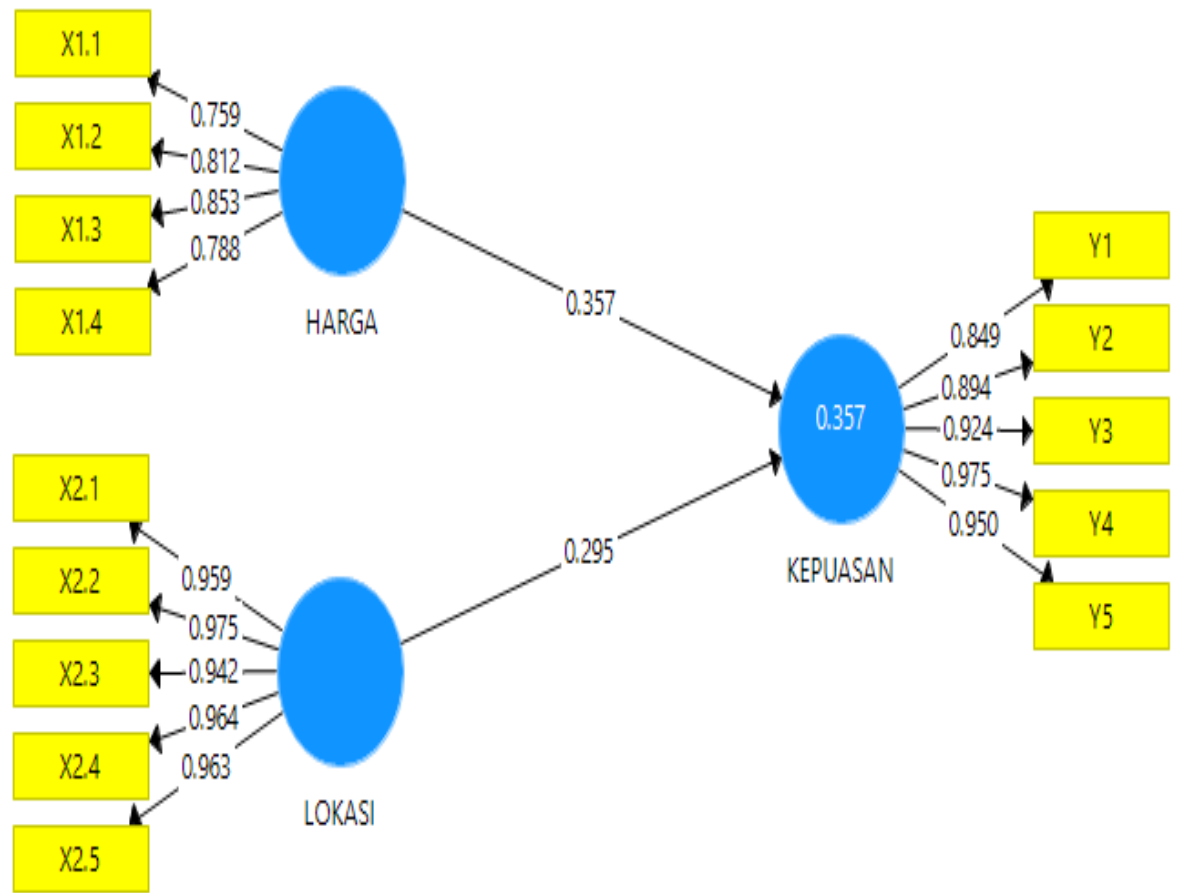

Gambar 2. Outer Model

Tabel 1. Convergent Validity dan AVE

\begin{tabular}{|c|c|c|c|}
\hline Variabel & Indikator & Outer Loading & AVE \\
\hline \multirow{4}{*}{$\begin{array}{c}\text { Harga } \\
(X 1)\end{array}$} & $\mathrm{X} 1.1$ & 0,759 & \\
\cline { 2 - 3 } & $\mathrm{X} 1.2$ & 0,812 & \multirow{4}{*}{0,646} \\
\cline { 2 - 3 } & $\mathrm{X} 1.3$ & 0,853 & \\
\cline { 2 - 3 } & $\mathrm{X} 1.4$ & 0,788 & \\
\hline \multirow{4}{*}{$\begin{array}{c}\text { Lokasi } \\
(\mathrm{X} 2)\end{array}$} & $\mathrm{X} 2.1$ & 0,959 & \\
\cline { 2 - 3 } & $\mathrm{X} 2.2$ & 0,975 & \\
\cline { 2 - 3 } & $\mathrm{X} 2.3$ & 0,942 & \\
\cline { 2 - 3 } & $\mathrm{X} 2.4$ & 0,964 & \\
\cline { 2 - 3 } & $\mathrm{X} 2.5$ & 0,963 & \\
\hline \multirow{3}{*}{$\begin{array}{c}\text { Kepuasan } \\
(Y)\end{array}$} & $\mathrm{Y} 1$ & 0,849 & \\
\cline { 2 - 3 } & $\mathrm{Y} 2$ & 0,894 & \\
\cline { 2 - 3 } & $\mathrm{Y} 3$ & 0,924 & \\
\hline
\end{tabular}




\begin{tabular}{|l|c|c|c|}
\hline Variabel & Indikator & Outer Loading & AVE \\
\hline & Y4 & 0,975 & \\
\cline { 2 - 3 } & Y5 & 0,950 & \\
\hline
\end{tabular}

Sumber : data diolah (2021)

Berdasarkan Tabel 1 terlihat bahwa uji validitas pada semua indikator penelitian ini telah memenuhi persyaratan penelitian. Artinya semua indikator berpengaruh terhadap variabel laten. Selain itu nilai Average Variant Extracted (AVE) variabel harga, lokasi dan kepuasan $>0,50$, dengan demikian dapat dikatakan bahwa setiap variabel memiliki validitas diskriminatif yang baik.

\section{Tabel 2. Discriminant Validity Test Result (Fornell Lacker Criterium)}

\begin{tabular}{|l|r|r|r|}
\hline & \multicolumn{1}{|c|}{ Harga } & \multicolumn{1}{c|}{ Kepuasan } & \multicolumn{1}{c|}{ Lokasi } \\
\hline Harga & 0,804 & & \\
\hline Kepuasan & 0,557 & 0,919 & \\
\hline Lokasi & 0,676 & 0,536 & 0,961 \\
\hline
\end{tabular}

Sumber : data diolah (2021)

Pada Tabel 2 perbandingan nilai AVE menampilkan hasil tiap-tiap nilai tersebut lebih besar dari pada korelasi antar variabel lain, sehingga bisa disimpulkan jika seluruh variabel laten dalam riset mempunyai validitas struktural serta diskriminasi yang baik.

\section{Hasil Uji Composite Reliability dan Cronbach's Alpha}

Tabel 3. Uji Composite Reliability dan Cronbach's Alpha

\begin{tabular}{|l|r|r|}
\hline \multicolumn{1}{|c|}{ Variabel } & Cronbach's Alpha & Composite Reliability \\
\hline Harga & 0,818 & 0,879 \\
\hline Lokasi & 0,979 & 0,984 \\
\hline Kepuasan & 0,954 & 0,965 \\
\hline
\end{tabular}

Sumber : data diolah (2021)

Dari hasil uji Cronbachs alpha dan reliabilitas komposit menunjukkan nilai yang menggembirakan karena semua variabel laten memiliki nilai cronbachs alpha dan reliabilitas diatas 0,70 yang berarti semua variabel laten dianggap reliabel.

\section{Hasil Uji R-Square}

Tabel 4. Hasil Uji R-Square

\begin{tabular}{|c|c|c|}
\hline & R Square & R Square Adjusted \\
\hline Kepuasan & 0,357 & 0,338 \\
\hline
\end{tabular}

Sumber : data diolah (2021)

Evaluasi koefisien determinasi $\left(\mathrm{R}^{2}\right)$ kepuasan sebesar 0,357 $\left(\mathrm{R}^{2}=35,7 \%\right)$, artinya presentase besarnya kepuasan orang tua murid dapat dijelaskan oleh harga dan lokasi sebesar $35,7 \%$ sedangkan selebihnya $64,3 \%$ dijelaskan oleh variabel lain diluar yang diteliti.

\section{Test Result of Goodness of Fit Model}

$\mathrm{Q}$-Square $=1-\left[\left(1-\mathrm{R}^{2}\right)\right.$

Q-Square $=1-(1-0,357)$

Q-Square $=1-0,643$

Q-Square $=0,357$

Diketahui bahwa melalui proses blindfolding variabel kepuasan memiliki nilai Q-Square sebesar 0,357 dengan demikian Q-Square $>0$. Artinya variabel dependen memiliki relevansi prediktif atau menjelaskan bahwa variabel independen memiliki relevansi prediktif terhadap variabel dependen yang terpengaruh.

\section{Pengujian Hipotesis}

Jika nilai sampel asli menunjukkan nilai positif maka variabel memiliki hubungan positif (begitu pula sebaliknya). Jika berdasarkan nilai T-statistik syarat T-statistics $>$ 1,96 (taraf 
signifikansi 5\%) dan nilai P-value harus lebih kecil dari 0,05 sehingga dapat disimpulkan bahwa hubungan antar variabel yang diuji dinyatakan memiliki pengaruh yang signifikan.

Tabel 5. Path Coefficient Result

\begin{tabular}{|c|l|c|c|c|c|}
\hline Hipotesis & Variabel & Original Sample & T Statistics & P Values & Ket \\
\hline H1 & Harga -> Kepuasan & 0,357 & 2,748 & 0,006 & Significant \\
\hline H2 & Lokasi -> Kepuasan & 0,295 & 2,407 & 0,016 & Significant \\
\hline
\end{tabular}

Sumber : data diolah (2021)

Dari hasil pengujian tersebut dapat terlihat pengaruh harga terhadap kepuasan memiliki nilai original sampel 0,357 (positif) dan $\mathrm{p}$ value 0,006 $<0,05$ yang berarti harga memiliki pengaruh signifikan terhadap kepuasan sehingga $\mathrm{H} 1$ diterima. Kemudian pengaruh lokasi terhadap kepuasan memiliki nilai original sampel 0,295 (positif) dan $p$ value $0,016<0,05$ yang berarti lokasi memiliki pengaruh signifikan terhadap kepuasan sehingga $\mathrm{H} 2$ diterima.

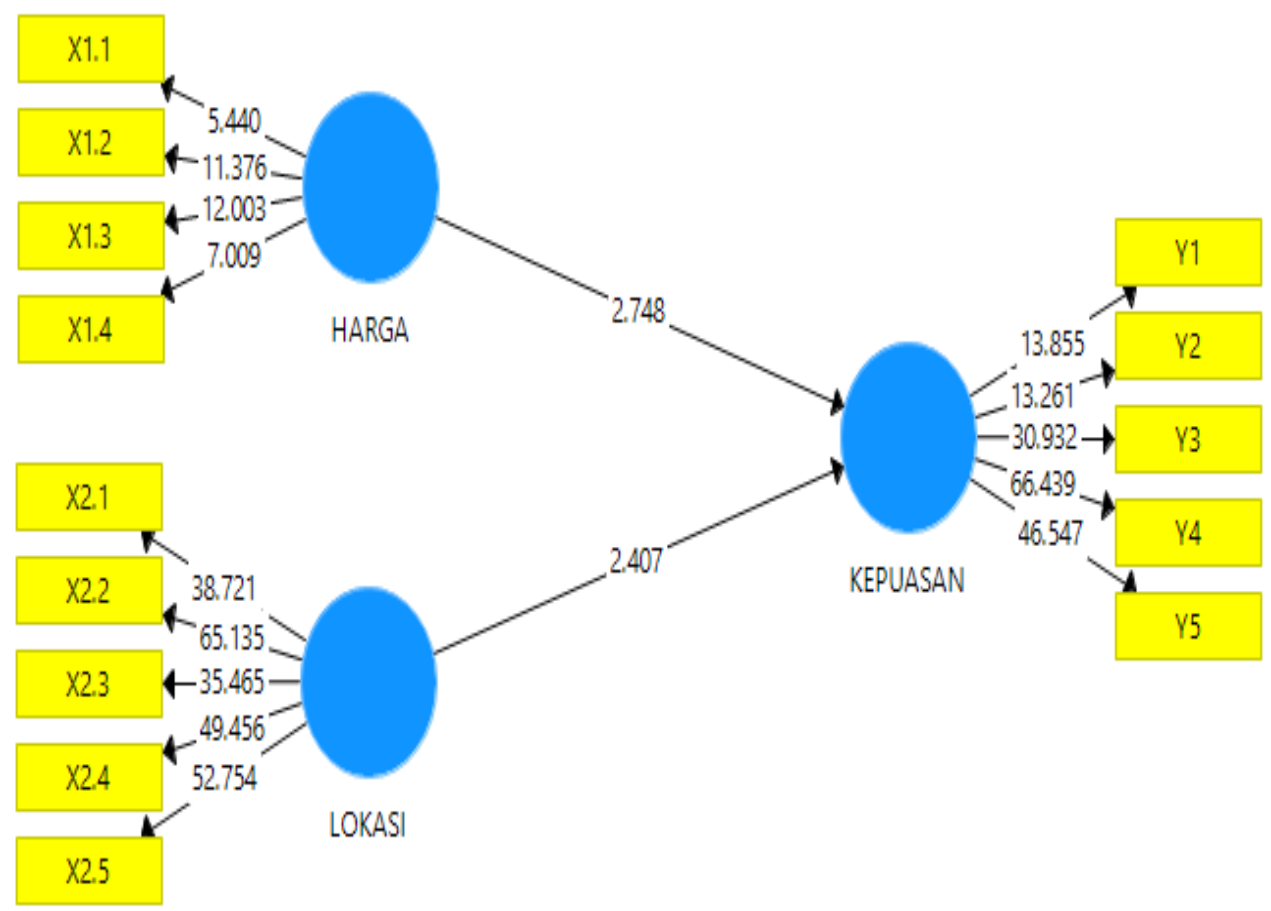

\section{Pembahasan}

Gambar 3. Inner Model

Hasil penelitian ini menegaskan bahwa harga dapat mempengaruhi kepuasan orang tua murid. Menurut Tjiptono (2016) Sukses tidanya suatu produk dipasaran tidak hanya ditentukan oleh pelayanan yang baik dari jasa tersebut akan tetapi juga ditentukan oleh faktor lain seperti salah satunya harga dalam memasarkan suatu barang atau jasa, setiap perusahaan harus menetapkan harganya secara tepat. Indikator daya saing harga memberikan nilai tertinggi sebesar 0,853, yang berarti peningkatan harga dapat tercipta terutama pada indikator daya saing harga. Hasil penelitian ini mendukung penelitian sebelumnya yang dilakukan oleh Firdiyansyah (2017) yang memperlihatkan hasil bahwa Harga secara parsial berpengaruh positif terhadap kepuasan pelanggan. Juga penelitian Nurhalimah, Hasiholan, dan Harini (2018), yang juga menyatakan bahwa Harga secara parsial berpengaruh positif terhadap kepuasan pelanggan.

Selain variabel harga, penelitian ini mencatat hasil bahwa lokasi berpengaruh signifikan terhadap kepuasan orang tua murid. Lokasi merupakan tempat untuk melaksanakan suatu usaha yang merupakan faktor krusial berhasil atau tidaknya suatu usaha (Tjiptono, 2016). Sedangkan menurut Kotler dan Armstrong (2016), lokasi adalah kegiatan perusahaan yang 
membuat produk tersedia bagi pelanggan sasaran. Pemilik usaha harus pandai dalam memilih lokasi sebagai tempat usaha tersebut dalam melakukan kegiatannya. Karena dengan memilih lokasi yang strategis dan juga nyaman akan lebih menguntungkan perusahaan, terlebih berlokasi dekat dengan aktivitas para pelanggan. Indikator visibilitas memberikan nilai tertinggi sebesar 0,975 yang berarti peningkatan lokasi dapat tercipta terutama pada indikator visibilitas. Temuan ini mengkonfirmasi penelitian sebelumnya oleh Firdiyansyah (2017) (2017) dalam penelitianya menyebutkan bahwa lokasi secara parsial berpengaruh positif terhadap kepuasan pelanggan pada Warung Gubrak Kepri Mall Kota Batam. Hal tersebut juga didukung oleh penelitian dari Isnaini (2018) yang menyatakan bahwa Lokasi secara parsial memiliki pengaruh signifikan positif terhadap kepuasan konsumen.

\section{Kesimpulan}

Penelitian ini memberikan kesimpulan bahawa harga memberikan pengaruh signifikan terhadap kepuasan Orang Tua Murid di MI Mathlaul Anwar Pamulang, hal tersebut menunjukan bahwa peningkatan harga yang wajar serta masih terjangkau oleh kemampuan Orang Tua Murid, maka kepuasan Orang Tua Murid di MI Mathlaul Anwar Pamulang juga akan meningkat. Lokasi memberikan pengaruh signifikan terhadap kepuasan Orang Tua Murid di MI Mathlaul Anwar Pamulang, hal tersebut menunjukan bahwa semakin strategis lokasi sekolah dan mudah di akses oleh peserta didik maka akan meningkatkan kepuasan Orang Tua Murid di MI Mathlaul Anwar Pamulang.

\section{Daftar Pustaka}

Alma, B. (2016). Manajemen Pemasaran dan Pemasaran Jasa. Bandung: Alfabeta.

Arif, S. (2016). Pengaruh Kualitas Layanan Terhadap Kepuasan Dan Loyalitas Orang Tua Siswa di MI NU Miftahul Huda 02 Piji Dawe Kudus Tahun Pelajaran 2015/2016. Quality. 4(1),

Firdiyansyah, I. (2017). Pengaruh Kualitas Pelayanan, Harga, Dan Lokasi Terhadap Kepuasan Pelanggan Pada Warung Gubrak Kepri Mall Kota Batam. Jurnal Elektornik REKAMAN (Riset Ekonomi Bidang Manajemen dan Akuntansi). 1(1).

Ghozali, I., \& Latan, H. (2017), Partial Least Square: Konsep, Metode, dan Aplikasi menggunakan program WarpPLS 5.0, Edisi ke-3, Semarang: Badan Penerbit Universitas Diponogoro.

Hair et. al (2014). Partial least squares structural equation modeling (PLS-SEM) An emerging tool in business research. European Business Review. 26(2).

Iskandarsyah, N.M., \& Utami S. (2017). Pengaruh Harga, Lokasi, Dan Fasilitas Terhadap Kepuasan Konsumen Pada Perumahan Murah Di Hadrah Property. Jurnal Ilmiah Mahasiswa Ekonomi Manajemen. 2(1). https://doi.org/10.24815/jimen.v2i1.3826.

Isnaini, S. (2018). Pengaruh Harga dan Lokasi Terhadap Kepuasan Pelanggan Studi Kasus Pada Lembaga Kursus dan Pelatihan (LKP) Andini Jombang. BIMA : Journal of Business and Innovation Management. 1(1).

Kotler, Philip and Gary Amstrong. (2016). Prinsip-prinsip Pemasaran. Edii13. Jilid 1. Jakarta: Erlangga.

Kotler, Phillip dan Kevin Lane Keller. (2016). Manajemen Pemasaran edisi 12 Jilid 1 \& 2.Jakarta: PT. Indeks

Lupiyoadi, Rambat dan Hamdani, A, (2011). Manajemen Pemasaran Jasa. Edisi. Kedua, Jakarta: Salemba Empat.

Nurhalimah, S., Hasiholan, L.B., \& Harini, C. (2018). Analisis Pengaruh Kualitas Pelayanan, Harga Dan Lokasi Terhadap Kepuasan Pelanggan (Studi pada Bengkel Garasi di Ungaran). Journal of Management. 4(4). 
Oktarini, R., \& Rahmayanti. (2020). Faktor-Faktor Yang Mempengaruhi Keputusan Orang Tua Dalam Memilih Lembaga Pendidikan (Studi Empiris Pada SMA Imtek Pagedangan Tangerang). Jurnal Ilmiah Ilmu Sekretari/Administrasi Perkantoran. 7(2).

Prasetia, A. (2019). Pengaruh Kualitas Pelayanan, Harga Dan Lokasi Terhadap Kepuasan Pelanggan Pada Villa Cahaya Pacet Mojokerto. Jurnal Ilmu dan Riset Manajemen. 8(11).

Singal, S. C., Koleangan, R. A. M., \& Jantje L. Sepang. (2019). Pengaruh Gaya Hidup, Harga Dan Lokasi Terhadap Minat Menonton Di Bioskop Cgv Blitz Cinemas Manado. Jurnal Emba, 7(3), 3009-3018.

Solihin, D. (2021). The Influence Of Brand Image And Atmosphere Store On Purchase Decision For Samsung Brand Smartphone With Buying Intervention As Intervening Variables (Study on Samsung Experience Store Karawaci Customers). International Journal of Social Science and Business. 5(2).

Solihin, D., \& Wibawanto, E. (2020). Pengaruh Kualitas Pelayanan, Harga, Dan Promosi Terhadap Keputusan Pelanggan Dalam Memilih Klub Basket Satria Indonesia Tangerang Selatan. Jurnal Pemasaran Kompetitif. 3(3), 30-36.

Solihin, D. (2020). Pengaruh Kepercayaan Pelanggan Dan Promosi Terhadap Keputusan Pembelian Konsumen Pada Online Shop Mikaylaku Dengan Minat Beli Sebagai Variabel Intervening. Jurnal Mandiri. 4 (1), 38 - 51.

Solihin, D., Susanto, N., Setiawan, R., Ahyani, \& Darmadi. (2020). Penerapan Strategi Pemasaran Sebagai Upaya Meningkatkan Usaha Kecil Dan Menengah Warga Di Kelurahan Paninggilan Utara Ciledug. Abdi Laksana Jurnal Pengabdian Masyarakat, 1(3). 351-355.

Sugiyono. (2017). Metode Penelitian Kuantitatif Kualitatif dan R\&D. Bandung: Alfabeta.

Tjiptono, F. (2016). Service, Quality \& satisfaction. Yogyakarta: Andi.

Tjiptono, F., dan Anastasia Diana. (2015). Pelanggan Puas ? Tak Cukup. Yogyakarta: Andi.

Windasuri, H., Hyachinta, S., \& Team, B. G. (2016). Excellence Service. Jakarta: PT Gramedia Utama 